Research Article / Araştırma Makalesi

\title{
THE GLOBAL FINANCIAL CRISIS AND CAPITAL STRUCTURE DECISIONS OF TURKISH SMES: A REVIEW
}

\author{
PhD. Hasan TEKIN \\ Karabük University, Safranbolu Vocational School, Karabük, Turkey, (hasantekin@karabuk.edu.tr) \\ Asst. Prof. Ali Yavuz POLAT \\ Abdullah Gul University, FEAS, Kayseri, Turkey, (aliyavuz.polat@agu.edu.tr)
}

\begin{abstract}
Due to the arising uncertainties with the global financial crisis, capital structure decisions became crucial for Turkish firms, especially small and medium-sized (SMEs) firms. Since SMEs face higher information asymmetry, transaction costs and risk, they face more difficulties in accessing finance during the financial market turmoil. In this review, we comparatively analyze findings from capital structure decisions for Turkish firms. As might be anticipated, we expect that SMEs should take more precautionary steps under the severe crisis conditions compared to listed firms in Borsa Istanbul.
\end{abstract}

Keywords: Capital Structure, Turkish SMEs, the Global Financial Crisis, Information Asymmetry, Risk, Transaction Costs.

\section{KÜRESEL FINANSAL KRİZ VE TÜRK KOBILLERININ SERMAYE YAPISI KARARLARI: BİR İNCELEME}

\begin{abstract}
ÖZET
Küresel finansal krizle birlikte belirsizlikler artmıs, böylece, sermaye yapısı kararları Türk firmaları, özellikle küçük ve orta ölçekli (KOBİ) firmalar için çok önemli hâle gelmiştir. KOBİ'ler daha yüksek bilgi asimetrisi, işlem maliyetleri ve riskle karşı karşıya olduğundan, finansal piyasalardaki kargaşa sirasında finansmana erişimde daha fazla güçlïkle karşılaşırlar. Bu incelemede, Türk firmalarının sermaye yapısı kararlarından elde edilen bulguları karşılaştırmalı olarak analiz ediyoruz. Tahmin edilebileceği gibi, ciddi kriz koşullarında KOBİ'lerin Borsa İstanbul'da listelenen firmalardan daha fazla önlem almasını bekliyoruz.
\end{abstract}

Anahtar Kelimeler: Sermaye Yapısı, Türk KOBİ'leri, Küresel Finansal Kriz, Bilgi Asimetrisi, Risk, İşlem Maliyetleri. 


\section{Introduction}

During turbulence periods, the supply of credit shrinks since lending reduces sharply. Moreover, the credit demand decreases as well. Both supply- and demand-side effects impact firms' capital structure choices. The Global Financial Crisis (GFC) offers a natural experiment opportunity to understand the capital structure decisions of firms around the globe. Specifically, Small and medium-sized enterprises (SMEs) seem to be affected significantly by the GFC. Considering the significant role of SMEs for emerging market economies, such as Turkey, this article reviews the literature to investigate the impact of the GFC on capital structure decisions of Turkish SMEs.

SMEs are the backbone of an economy considering their share in total firms: Namely, SMEs constitute a share $95 \%$ in the total number of firms, and a share of $60 \%-70 \%$ of total employment in Organization for Economic Co-operation and Development (OECD) economies (OECD, 2006). Specifically, in Turkey, SMEs constitute more than $99 \%$ of the total number of firms and share of SMEs' workforce in total employment is 78\% (Small and MediumSized Enterprises Development Organization of Turkey (KOSGEB), 2012). However, despite their significance and importance in the economy, SMEs usually face information asymmetry problems, higher risk and transaction costs more than larger firms. Consequently, SMEs should make effective capital structure decisions to minimize these problems and maximize their value.

The literature mentions that the GFC has a negative impact on capital structure decisions of Turkish firms. For example, Y1ldız (2018) and Jermias \& Yigit (2019) show that Turkish firms decreased their adjustment speed of capital structure after the GFC. Typically, these studies use the dataset of Borsa Istanbul (BIST) in which mainly larger firms are listed. Besides, Köksal \& Orman (2015) and Orman \& Köksal (2017) examine the structure and maturity of debt of both Turkish listed and unlisted firms by employing the Central Bank of Republic of Turkey (CBRT) dataset. To the best of our knowledge, interestingly, no single research has mentioned the effect of the GFC on capital structure decisions of Turkish unlisted firms or SMEs. That is why this research contributes to the literature by offering a possible research avenue on the capital structure decisions of Turkish SMEs in the GFC context.

The rest of the paper proceeds as follows. In section 2, firstly the importance of capital structure will be indicated by informing of the nature and criticality of capital structure decisions. Secondly, three main capital structure theories, trade-off theory, pecking order theory and signaling theory are analyzed. Then, the reason for selecting these theories are explained in detail. Thirdly, the optimal capital structure theory and its relation to selected theories are mentioned. After that, for all three theories separately: (1) the essentials of the theory will be specified, (2) the critical evaluation of the theory is demonstrated carefully by discussing the possibility of dynamic convergence. Finally, the influence of the GFC on capital structure decisions is reviewed for the selected empirical research.

In section 3, firstly Turkish SMEs' characteristics are explained. Then, the main financial obstacles of Turkish SMEs: adverse selection, moral hazard, credit rationing and transaction costs are mentioned. By doing this, the emergence of asymmetric information on the borrowerlender transaction is pointed out and the relationship between causes of these obstacles in relation to three previously specified theories are shown. 
In section 4, the relationship between the aforementioned three theories and Turkish SMEs are analyzed by critically evaluating methodological applications of these theories in Turkey based studies. Next, section 5 summarizes recent research, which applies BIST or CBRT datasets and their relation to the GFC. Lastly, section 6 concludes.

\section{The Capital Structure Decision Theories}

Modigliani and Miller (MM) (1958) argued that there is no relationship between capital structure and the firm value. While MM's approach is difficult to test, outcomes in financial markets seem to support it (Myers, 2001). Following this approach of financial theory, which opens new horizons, many researchers studied on effective factors of firms' capital structure.

Capital structure focuses on financing mix of debt and equity. In other words, capital structure is the resource combination of firms used to finance their assets. Firms can use either their own funds to finance the value increasing investment opportunities or external finance to benefit from the tax savings with the help of financial leverage. Thus, capital structure is crucial for firms' survival and value both in short- and long run especially for SMEs which are the main driving force of economic growth. capital structure may differ depending on the nature of the industry and the size of firms. The banking industry, for instance, is known to be high-levered and equity ratios are usually significantly lower than other industries such as manufacturing. This heterogeneous nature of the different industries opens a fruitful area of research for academics; this is why capital structure is extensively investigated in the literature due to its relevance and importance.

For this study, three major theories; trade-off theory, pecking order theory and signaling theory, have been chosen, while there are many other capital structure decision theories: irrelevancy theory, agency theory, market timing theory and so on. As to the reason of for selecting these theories, capital structure decisions of Turkish SMEs will be analyzed to find which theory has the most explanatory power on capital structure decisions. Regarding the SME literature, López-Gracia \& Sogorb-Mira (2008) and Köksal \& Orman (2015) focus on trade-off theory and pecking order theory, whereas Brau \& Carpenter (2012) focus on signaling theory to explain capital structure decisions of SMEs.

Optimal capital structure refers to the equilibrium established as the optimum trade-off between the tax advantages of debt and the costs of bankruptcy and agency, which are caused by debt (Myers, 2001). Therefore, trade-off theory is an optimal capital structure. However, Myers (1984) mentions that firms do not optimize debt-to-equity ratio in pecking order theory. Ross (1977) demonstrated that the high leverage ratio is an indicator of a good quality signal for an investor in signaling theory. Consequently, neither pecking order theory nor signaling theory is an optimal capital structure. In the following parts, trade-off theory, pecking order theory and signaling theory will be explained.

\subsection{Trade-off Theory}

MM (1963) recommended that firms who pay corporation tax will choose the maximum debt. Then, Kraus \& Litzenberger (1973) developed trade-off theory demonstrating that the optimal leverage should trade-off between bankruptcy costs and tax benefits of debt. Thus, 
contrary to MM (1963), due to the cost of debt optimal capital structure choice is no longer the maximum debt.

The most obvious indicator for the cost of debt is bankruptcy cost or financial distress (Frank \& Goyal, 2008). The benefits of debt include the tax benefit of interest and decreased free cash flow problems. However, costs of debt arise from bankruptcy costs and agency costs, which occur due to the conflicts of interest between shareholders and debt holders.

Trade-off theory is analyzed both with static and dynamic models. While the static model targets an optimal capital structure in a single period, the dynamic model focuses on a target-adjustment over time.

\subsubsection{Static Trade-off Theory}

Trade-off models arise from discussions of MM's propositions on taxes and financial distress costs. According to the static trade-off theory, the value after-tax increases with the change in present value of the tax shield. However, the more financial leverage the firm has, the more likely it is to suffer financial distress. Consequently, the firm value will decrease as the change in present value of financial distress costs. static trade-off theory determines an optimal capital structure analyzing the market imperfections like taxes, financial distress costs and agency costs under MM's assumptions of market efficiency and symmetric information. As seen in Figure 1, the firm achieves the optimal capital structure when the present value of tax savings offset by an increase in the value of the current cost of financial distress.

According to trade-off theory, the benefits and costs of the debt can be achieved in different ways of determining capital structure (Myers, 2001). Firstly, firms set the optimal debt ratio by trading off between the tax benefits of debt and financial distress costs. Secondly, debt mitigates the conflicts of interest between shareholders and managers, whereas it may intensify the conflicts of interest between shareholders and debt holders considering agency costs. When static trade-off theory is inadequate on certain issues regarding the use of debt, agency cost models explain some of these issues which are related to shareholder-debt holder conflicts (Jensen \& Meckling, 1976).

\subsubsection{Dynamic Trade-off Theory}

The long-term leverage targets of firms have been a major subject of capital structure research. Thus, the speed of adjustment to the target is discussed by dynamic trade-off theory. Dynamic models argue that firms do not deviate from the target ratio when there is no adjustment cost. Conversely, while the adjustment cost is at the maximum point, these firms will not obtain a target ratio (Flannery \& Rangan, 2006).

The leverage tends to return to optimum in the long-run, so-called mean reversion, which is not surprising considering the evidence that the leverage is almost constant in the long term (Fama \& French, 2002). Furthermore, Fischer et al. (1989) claimed that the use of a partial adjustment model is necessary for explaining partial adjustments and determining the speed of adjustment. Thus, adjustment costs prevent full adjustment in each period to the target leverage ratio. 
Figure 1: Static Trade-off Theory and Optimal Capital Structure

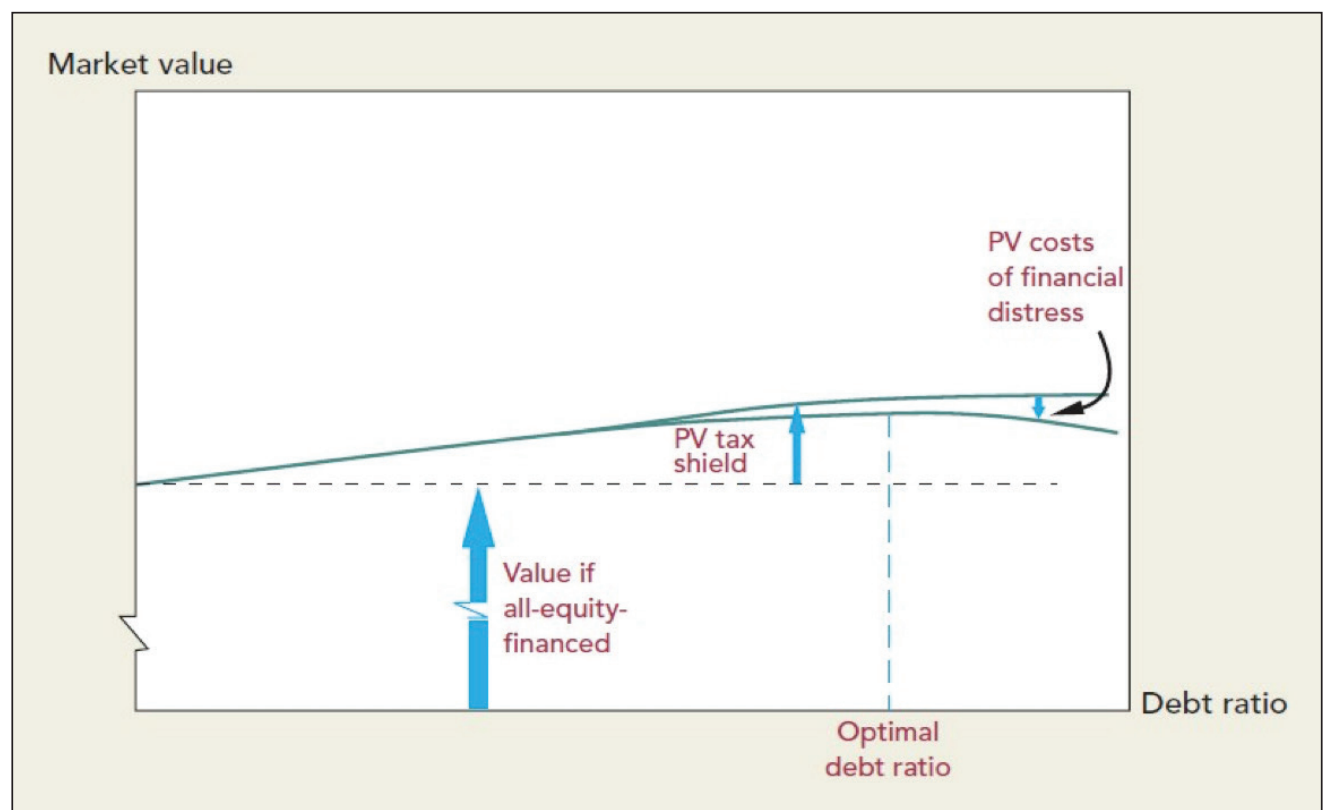

Source: Brealey, R. A., Myers, S. C., \& Allen, F. (2014). Principles of corporate finance. 11th Edition, Berkshire: McGraw-Hill Education, s.447.

\subsubsection{Empirical Research on Trade-off Theory}

According to static trade-off theory, using debt helps firms to avoid tax, so it is expected that with higher tax there will be more debt finance. An increase in bankruptcy costs makes equity more advantageous. Thus, the leverage ratio is while positively related to tax benefits, negatively related to the financial distress (Bradley et al., 1984; Graham \& Harvey, 2001; Titman \& Wessels, 1988).

Since firms having higher profits have a lower probability of financial distress and higher benefit of tax shields, static trade-off theory expects a positive relationship between leverage and profitability. However, some scholars (Frank \& Goyal, 2008; Kayhan \& Titman, 2007; Rajan \& Zingales, 1995) showed a negative relationship between leverage and profitability. These seemingly contradicting results can be explained by the dynamic extension of trade-off theory since dynamic version can generate a negative relation (Morellec, 2004; Tserlukevich, 2008). 
Table 1: Summary of Methodology Applications on Trade-off Theory

\begin{tabular}{llll}
\hline Author & Model & Sample & Result \\
\hline Bradley et al. (1984) & Static & 851 Compustat firms (1962-1981) & Support \\
\hline Titman \& Wessels (1988) & Static & 469 US firms (1974-1982) & Support \\
\hline Fischer et al. (1989) & Dynamic & 999 Compustat firms (1977-1985) & Support \\
\hline Rajan \& Zingales (1995) & Static & G-7 countries (1987-1991) & Support \\
\hline Graham (2000) & Static & 87,643 Compustat firms (1973-1994) & Not support \\
\hline Hovakimian et al. (2001) & Static & 39,387 firms (1979-1997) & Support \\
\hline Graham \& Harvey (2001) & Static & 392 responses in 4,610 firms (1998) & Support \\
\hline Fama \& French (2002) & Dynamic & over 600 firms (1973-2002) & Support \\
\hline Leary \& Roberts (2005) & Dynamic & 3,494 firms (1984-2001) & Support \\
\hline Flannery \& Rangan (2006) & Dynamic & 12,919 Compustat firms (1965-2001) & Not support \\
\hline Kayhan \& Titman (2007) & Static & Compustat firms (1960-2003) & Support \\
\hline Strebulaev (2007) & Dynamic & 3,000 Compustat firms (1965-2000) & Support \\
\hline Frank \& Goyal (2008) & Static & US non-financial sectors (19452002) & Support \\
\hline Lemmon et al. (2008) & Dynamic & Compustat firms (1965-2003) & Support \\
\hline Tserlukevich (2008) & Dynamic & 1,000 Compustat firms (300 quarters) & Support \\
\hline Faulkender et al. (2012) & Dynamic & Compustat firms (1965-2006) & Support \\
\hline Strebulaev \& Yang (2013) & Static & Compustat firms (1962-2009) & Support \\
\hline & & &
\end{tabular}

As stated by Strebulaev \& Yang (2013), many firms are giving up these tax advantages choosing zero leverage. However, Graham (2000) argues the debt tax shield is underutilized and the level of debt is below the optimal. The majority of Compustat firms, which have low financial distress costs, avoid the use of debt and prefer less leverage.

Hovakimian et al. (2001) indicate that firms use more debt to finance current assets while they use more equity to finance growth opportunities. Thus, they propose that the issuance of equity rather than debt can be preferred when the perceived growth opportunities increase the value of the firm. This observation is consistent with the idea that stock price increases are usually associated with increased growth opportunities that will reduce the firm's optimal debt ratio. A negative relationship between historical stock prices and increasing leverage is consistent with agency costs models which claim that managers tend to increase leverage when stock prices are low. In trade-off theory, firms always focus on achieving the optimal capital structure, but in reality, they occasionally adjust due to adjustment costs. If adjustment costs are small leverage can change significantly (Fischer et al., 1989; Leary \& Roberts, 2005; Strebulaev, 2007). Thus, firms adjust their capital structre when adjustment benefit is high or adjustment cost is low (Faulkender et al., 2012).

Lemmon et al. (2008) argue that firms that actively manage leverage and make adjustments, move towards a time-invariant target. Empirical evidence confirms that the firms 
aim to achieve a target debt ratio (Flannery \& Rangan, 2006; Hovakimian et al., 2001; Kayhan $\&$ Titman, 2007). But different results found about the speed of adjustment process. Fama \& French (2002) claim that since large adjustments are costly the process is very slow. Whereas, Leary \& Roberts (2005) find that the adjustment process is fast. As opposed to time-invariant leverage target findings, Hovakimian et al. (2001) argue that firms may face obstacles when moving towards the target rate which may vary in time by changing the firm profitability and stock prices. As an alternative explanation, Cook \& Kieschnick (2009) claim that under the dynamic model managers with bounded rationality can cause a partial adjustment to the target ratio.

\subsection{Pecking Order Theory}

The financial hierarchy was proposed first time by Donaldson (1961) for long-term financial strategies of firms. Myers \& Majluf (1984) and Myers (1984) developed pecking order theory prioritizing internal sources of funds, debt and equity respectively. The financial hierarchy, as shown in Table 2, occurs when the cost of issuing new shares is greater than the cost of debt and dividend. Financial hierarchy costs consist of costs associated with the issuance of new shares and costs arising from the management to have more information regarding the firm's expectations and the real value of risky stocks. Firms finance their new investments with retained earnings firstly, secured debt secondly and then equity if they are in a very difficult situation (Myers, 2001). As a result, the changes in the firm's leverage are determined by the firm's net cash flow in pecking order theory, not by debt's benefits and costs as in trade-off theory.

\section{Table 2: The Financial Hierarchy}

\begin{tabular}{lcc}
\hline Financing choice & Source & Adverse selection \\
\hline Internal funding & Inside & No \\
\hline Debt issuance & Outside & Low \\
\hline Equity issuance & Outside & High \\
\hline
\end{tabular}

Source: Brealey, R. A., Myers, S. C., \& Allen, F. (2014). Principles of corporate finance. 11th Edition, Berkshire: McGraw-Hill Education, s.460.

\subsubsection{Asymmetric Information in Pecking Order Theory}

Asymmetric information mentions that managers have more information than outsiders about the firm's expectations, risks and value. If a firm pays more dividends, its stock prices rise. Thus, investors perceive this situation as a signal of confidence regarding the future income of the firm.

Consequently, an increase in dividend provides a flow of information from managers to investors. Moreover, debt issuance is preferable to equity issuance for managers who have optimistic expectations related to the future of the firm (Brealey et al., 2014). 
However, it is considered that when managers have more information than investors about the real value of the firm, if the stock market price is above managers' expectations, equity will be issued. Investors, who are aware of the existence of information asymmetry, interpret equity issuance announcements as a signal that stocks are overvalued which will then result in a negative price effect (Myers \& Majluf, 1984). Thus, equity can be mispriced by the market due to adverse selection.

\subsubsection{Empirical Research on Pecking Order Theory}

According to the pecking order theory, the capital structure depends on the profitability of the firm and investment opportunities. Highly profitable firms can use retained earnings whereas firms with lower profits have to depend on debt for financing their investments (Booth et al., 2001; Huang \& Song, 2006; Rajan \& Zingales, 1995). Moreover, Shyam-Sunder \& Myers (1999) found strong support for pecking order theory, especially for established firms. Furthermore, Degryse et al. (2012) find that, in support with pecking order theory, SMEs reduce their debt level using profits. Gonzalez \& Gonzalez (2012) have added that a negative relationship between debt and profitability exists.

Having a larger sample Frank \& Goyal (2003) argued that when the financing gap increases, the equity issuance increased faster than the debt issuance. Similarly, Strebulaev \& Yang (2013) showed that many firms which seem to have easy access to debt finance still prefer equity financing. Consequently, pecking order theory alone cannot explain by itself the empirical findings.

Claiming that adverse selection costs determine the financing behavior, pecking order theory is expected to perform better particularly in firms faced with serious adverse selection problems. According to the same result of Ghosh et al. (1999), Fama \& French (2002), Frank \& Goyal (2003) and Lemmon \& Zender (2010), SMEs with high-growth rate prefer to issue more equity.

After the initial public offering, Frank \& Goyal (2008) reveal that equity issuance is more important for SMEs than larger firms. According to Frank \& Goyal (2003), when the firm size increases, financing hierarchy estimates also indicate better performance. While the findings of larger firms support pecking order theory, the implications of pecking order theory cannot be observed in SMEs. Moreover, SMEs with a high-growth rate have more restrictive debt capacity constraints. According to this argument, common equity issuances made by SMEs do not contradict to pecking order theory (Lemmon \& Zender, 2010). 
Table 3: Summary of Methodology Applications on Pecking Order Theory

\begin{tabular}{lcc}
\hline Author & Sample & Results \\
\hline Rajan \& Zingales (1995) & 8,000 firms in G-7 countries (1987-1991) & Support \\
\hline Ghosh et al. (1999) & 238 firms (1991-1995) & Support \\
\hline Shyam-Sunder \& Myers (1999) & 157 firms (1971-1989) & Support \\
\hline Booth et al. (2001) & 10 developing countries (1980-1991) & Support \\
\hline Fama \& French (2002) & 3,000 firms (1965-1999) & Support \\
\hline Frank \& Goyal (2003) & 2,823 US firms(1971-1998) & Support \\
\hline Huang \& Song (2006) & 1000 China firms (1994-2000) & Support \\
\hline Frank \& Goyal (2008) & US non-financial sectors (1945-2002) & Support \\
\hline Lemmon \& Zender (2010) & Compustat firms (1971-2001) & Support \\
\hline Degryse et al. (2012) & Dutch SMEs (2003-2005) & Support \\
\hline Gonzales \& Gonzales (2012) & 3,439 Spanish firms (1995-2003) & Support \\
\hline Strebulaev \& Yang (2013) & Compustat firms (1962-2009) & Support \\
\hline
\end{tabular}

\subsection{Signaling Theory}

ST has been developed by Spence (1973), Ross (1977) and Bhattacharya (1979) in the contexts of job market signaling, incentive-signaling and dividend-signaling respectively. As stated by Spence (2002), signaling theory is substantially related to decreasing asymmetric information between two parties (the sender and the receiver). Spence (1973) demonstrated the signaling equilibrium in the job market by extending Akerlof (1970)'s argument, which is related to the uncertainty of quality and price. Spence (1973) illustrated that the selection of a prospective employee in a job application has been made with the help of signals. Consequently, high-quality prospective employees, as an example, may distinguish from lowquality prospective employees by showing their education level as a signal of ability.

Furthermore, Leland \& Pyle (1977) and Ross (1977) noted that there is asymmetric information through the stakeholders of the firm. It is likely that conflicts of interest may arise between the manager, who has complete information, and stakeholders, who do not have this information. The manager tries to solve this problem by transmitting his/her information to stakeholders as a signal.

According to Leland \& Pyle (1977), the value of the firm is related positively to managerial ownership. When the managerial ownership in the firm's capital is high, the debt capacity will increase. Therefore, there is a positive reaction of the market on debt issuance. Moreover, shareholders of the firm notice strong ownership which has been perceived as a signal of confidence for the future investments of the firm.

Ross (1977) has developed Leland and Pyle's analysis and introduced the signaling concept into the capital structure theory. According to this concept, while the manager knows the right distribution of the firm's earnings, investors do not know. Ross (1977) argues that the 
manager uses high financial leveraging as a signal for the future earnings of the firm. Moreover, investors perceive high debt levels as a signal of high-quality. As a result, low-quality firms have more marginal bankruptcy costs, so these firms may not imitate high-quality firms by issuing more debt in a separating equilibrium.

Bhattacharya (1979) points out that dividend payment may be used as a costly mechanism in order to signal the quality of the future earnings and cash flows which may help to overcome the information asymmetry between shareholders and the manager. Firms paying dividends will be perceived by the investor as a negative indicator of future cash flows.

\subsubsection{Empirical Research on Signaling Theory}

Dividend policy discussions first started with MM (1961) in modern corporate finance context. Thereafter, many scholars analyzed the dividend issue in various contexts as follows. In dividend earning relation context, Nissim \& Ziv (2001) and Zhou \& Ruland (2006) show that future earnings of firms are positively related to dividend payout over time. Consequently, dividends include information about future profitability, so high dividend payout can be used by firms to signal strong future earnings. Loughran \& Ritter (1997), similar to Jain \& Kini (1994), argued that equity issuing firms show high performance which is in line with the negative relationship between debt and profitability finding of the literature. This result is contrary to the theoretical implication, which suggests that profitability and debt should be positively related since high-quality firms are expected to issue debt in a separating equilibrium.

According to Amin et al. (2015), dividend announcements do not cause any market reactions contrary to Brennan \& Kraus (1987) model. Therefore, the model prediction and evidence on the announcement reaction relation can differ, meaning dividend may not be used as a signal in reality. By analyzing the leverage, the evidence of Shah (1994) does not support the prediction that by leverage-decreasing and leverage-increasing offers, information is revealed about economic conditions. Leverage-decreasing offers, for example, may cause prolonged underperformance due to financial distress, so this case is understood as a signal of retrenchment for firms. When the leverage increase is the issue, Masulis (1980) and Baker et al. (2003) showed a positive relationship between the market reaction and leverage-increasing transactions which support signaling theory. These results may be related to the ownership structure and financing options of the firms. Especially for SMEs, there are no significant agency issues and they may not need to use dividends as a signaling device.

Empirical findings always support signaling theory prediction that share prices should drop on equity issuance announcement, whereas for the announcement of debt the findings are contrasting with the signaling theory. Antweiler \& Frank (2006) showed negligible changes in stock prices as a response to debt announcement as well as Eckbo (1986). Jegadeesh \& Titman (1993) in their seminal paper analyze the effect of different news on the stock market, the socalled market momentum, and try to see whether firms can signal their future. Antweiler \& Frank (2006) suggest that monitoring the stock market momentum daily (or less than a week) rather than monthly may reveal better information. 
Table 4: Summary of Methodology Applications on Signaling Theory

\begin{tabular}{lcc}
\hline Author & Sample & Result \\
\hline Masulis (1980) & Exchange offers (1962-1976) & Support \\
\hline Eckbo (1986) & 723 debt offerings (1964-1981) & Not support \\
\hline Jegadeesh \& Titman (1993) & NYSE stocks (1965-1989) & Not support \\
\hline Jain \& Kini (1994) & 682 IPOs (1976-1988) & Not support \\
\hline Shah (1994) & 366 exchange offers (1970-1988) & Not support \\
\hline Loughran \& Ritter (1997) & Equity offerings (1979-1989) & Not support \\
\hline Nissim \& Ziv (2001) & 100,666 observations (1963-1998) & Support \\
\hline Baker et al. (2003) & 192 financial executives (1998-1999) & Support \\
\hline Antweiler \& Frank (2006) & 245,429 corporate stories (1973-2001) & Not support \\
\hline Zhou \& Ruland (2006) & Compustat firms (1950-2003) & Support \\
\hline Amin et al. (2015) & Dividend announcements (2002-2012) & Not support \\
\hline
\end{tabular}

\subsection{Capital Structure Decisions and the Global Financial Crisis}

With the rise of the financial crisis 2007-2009, firms shorten the structure and maturity of debt because of increased information asymmetry, risk and transaction costs. The empirical literature mentions that larger firms, as well as small firms, made critical changes on their capital structure and debt maturity (Alves \& Francisco, 2015; Gonzalez, 2015; Zeitun et al., 2017; Mimouni et al., 2019; D’Amato 2019; Demirgüç-Kunt et al., 2020). Regarding the international sample, Alves \& Francisco (2015) and Gonzalez (2015) show that firms shorten their maturity of debt for listed firms during the GFC owing to the decrease in supply of credit and demand for credit. More recently, Demirgüç-Kunt et al. (2020) found that small firms faced more problems in accessing finance during and after the GFC. For firms in six Gulf Cooperation Council (GCC) countries, Zeitun et al. (2017) and Mimouni et al. (2019) mention that firms in GCC countries reduced borrowing and shortened the maturity of debt. Specifically, D'Amato (2019) demonstrates that Italian SMEs decreased their leverage and debt maturity.

Table 5: Summary of Recent Selected Studies on Capital Structure Decisions and The GFC

\begin{tabular}{lccc}
\hline Author & Sample \& Period & Firms & $\begin{array}{c}\text { GFC } \\
\text { impact }\end{array}$ \\
\hline Alves \& Francisco (2015) & International sample 2000-2011 & Listed firms & Negative \\
\hline Gonzalez (2015) & International sample 1995-2012 & Listed firms & Negative \\
\hline Zeitun et al. (2017) & Six GCC countries 2003-2013 & Listed firms & Negative \\
\hline Mimouni et al. (2019) & Six GCC countries 2003-2013 & Listed firms & Negative \\
\hline D’Amato (2019) & Italian SMEs 2006-2016 & SMEs & Negative \\
\hline Demirgüç-Kunt et al. (2020) & International sample 2004-2011 & Private firms & Negative \\
\hline
\end{tabular}




\section{The Characteristics of Turkish SMEs}

SMEs are usually classified into three categories, micro, small and medium-sized enterprises. According to the revised SME definition of European Union (EU), micro enterprises have 1-9 workers and an annual turnover less than $€ 2$ million, small enterprises have 10-49 workers and an annual turnover less than $€ 10$ million and lastly, medium-sized enterprises have 50 to 249 workers and an annual turnover less than $€ 50$ million (OECD, 2005: 17).

The number of SMEs in Turkey is around 3.2 million. The sub-sectors of the SME sector in Turkey can be classified as follows: the repair of motor vehicles together with the wholesale and retail trade (roughly 40\%), storage and transportation industries $(16.4 \%)$ and the manufacturing industry $(12.8 \%)$. SMEs play a significant role as the driver of the Turkish economy due to their share in total number of firms (over 99\%) and the large share in total employment (over 78\%). Moreover, according to KOSGEB, in 2010 Turkish SMEs constitute approximately a share of $65 \%$ in total turnover and a share of $60 \%$ in total exports (KOSGEB, 2012).

SMEs in Turkey have lower labor and annual turnover compared to their counterparts in the EU and OECD countries. Additionally, since Turkish SMEs have limited know-how, lack of enough skill level and the amount of capital, and lack of access to modern technology; they face difficulties in accessing finance (World Bank, 2011). The long-term strategy on training, R\&D, administrative regulations, competitive policy, labor market, social policies and the national banking sector requires the participation of Turkish SMEs in the financial markets (Seker \& Jenkins, 2015).

\subsection{Financial Constraints of Turkish SMEs}

The main financial constraints of SMEs, namely asymmetric information, higher risk and transaction costs, affect SMEs' capital structure decisions. Thus, specifying the reasons for these constraints is important for understanding the capital structure of SMEs. Consequently, explaining the relationship between these constraints and the aforementioned three theories will help to make predictions on Turkish SMEs.

\subsubsection{Asymmetric Information}

A loan contract regulates rights and obligations between the borrower and the lender, but different situations, which are the estimation of the full debt repayment capability and the borrower's promise to adhere to the contract, may occur in the process of paying the debt. These situations can be problematic as the so-called information asymmetry that comprises when one party (borrower) has better or more information than the other party (lender).

Specifically, in the credit market, for SMEs, information asymmetry can be defined as the lack of relevant information between the SMEs demanding credit and the ones providing credit (Berger, 2006). It can be either due to the lack of information about lending institutions that provide loans or SMEs' lack of information about credit markets and institutions.

Pecking order theory demonstrates how financing can be affected by information differences (Myers, 1984). In addition, signaling theory shows informational feedback (Spence, 1973). Therefore, both of these theories focus on asymmetric information which leads to the emergence of two basic problems: adverse selection and moral hazard. 
When the borrower has more information than the lender before the transaction, adverse selection arises due to hidden information. The lemon problem, which has been stated by Akerlof (1970) and extended by Spence (1973), arises in financial markets. If the lender may not differentiate between the credit risk bearing projects allocating the credit, he/she will be faced with adverse selection. So long as the expected return is the same for two projects, the lender prefers the most reliable one whereas the borrower prefers the riskiest one (Bebczuk, 2003). In this case, the borrower, who prefers risky projects, hides the true nature of the project, exploiting the lack of information of the lender.

When the borrower has more information than the lender after the transaction, moral hazard occurs because of hidden action. Borrowers have the urge to deal with activities that increase the risk and probability of default which may harm the lender (Mishkin, 2007). A similar problem in the lender-borrower relationship can be seen in the principal-agent relationship. If the agent prioritizes his/her interests, the principal will use the monitoring system to minimize the moral hazard (Jensen \& Meckling, 1976). Consequently, moral hazard can be eliminated when all actions of the borrower and the lender are observable.

However, credit institutions may ration credit due to the worry about adverse selection (Stiglitz \& Weiss, 1981). Credit rationing occurs in two ways: firstly, despite that the claimant agrees to borrow with a high-interest rate, the lending institution still may not give any credit. Secondly, the institution may provide a credit level which is below the amount requested by the borrower (Arnold et al., 2014). Consequently, credit institutions prefer to ration credit instead of charging higher interest rates. Under the adverse selection problem, when the interest rate increases, high-risk individuals tend to borrow, and low risk individuals withdraw from the market not preferring to borrow at this rate. Thus, lending institutions cannot distinguish between higher repayment capability borrowers and lower repayment capability borrowers. For the Turkish economy, there are studies focusing on asymmetric information and credit rationing (Erdoğan, 2008; Muslumov \& Aras, 2004; Okuyan, 2009). They showed that when adverse selection exists, institutions ration credit in order to prevent any possible future loss.

\subsubsection{Risk Profile}

External funders/debtors may consider SMEs as risky due to a number of reasons: Firstly, SMEs usually face difficulty in their fiscal conditions compared to their larger counterparts due to the competition, so that SMEs may have a higher failure rate. Secondly, considering capital and human resources, SMEs have insufficient production equipment. Lastly, the accounting system used by SMEs seems to be inadequate to get information on repayment capacity and profitability (Arnold et al., 2014). These aforementioned problems are observed particularly in Turkish SMEs.

\subsubsection{Transaction Costs}

Transaction cost economics (TCE) propose to take make-or-buy decision to the manufacturers (Walker \& Weber, 1984). Therefore, TCE can be observable particularly in the manufacturing sector because manufacturers focus on minimizing the overall production costs. The production needs more time, money, production places and workers. Specifically, SMEs do not have many of these facilities, so they prefer to buy the required materials. 
Developed countries have roughly fixed the problem of transaction costs, whereas developing countries still face transaction costs due to the following reasons. Firstly, financial institutions do not manage information systems properly. Secondly, the information industry seems to be under-developed. Lastly, the existing public services are poor (Tadelis \& Williamson, 2012). Considering SMEs in Turkey, establishing a private SME exchange stock market may help to overcome these problems.

\section{Link Between Capital Structure Theories and Turkish SMEs}

The empirical literature of capital structure theories based on Turkish firms and the inferences of this literature particularly for SMEs are presented below. Table 5, Table 6 and Table 7 summarize methodology applications on pecking order theory, trade-off theory and signaling theory respectively for Turkish firms.

\subsection{Pecking Order Theory Versus Trade-off Theory}

As stated by the theoretical framework, pecking order models suggest a negative relationship between debt and profitability. Yildiz et al. (2009) found that profitability and debt are negatively correlated and also argued that there is a positive relationship between capital structure and firm size. Similarly, the same negative relationship has been confirmed by many scholars (Acaravcı \& Doğukanlı, 2004; Ata \& Ag, 2010; Demirhan, 2009; Durukan, 1997; Karadeniz, 2008). Kula (2000), Gülşen \& Ülkütaş (2012) and Uyar \& Güzelyurt (2015) have claimed that the SMEs do not have a target debt ratio and use financing in a pecking order. Bozkurt (2014) mentioned that there is a positive relationship between debt rates and the marketing value of the firms. These empirical studies agree on the conclusion that pecking order theory fits better for Turkish SMEs' capital structure decisions.

Table 6: Summary of Methodology Applications on Pecking Order Theory for Turkish Firms

\begin{tabular}{lcc}
\hline Author & Sample & Results \\
\hline Durukan (1997) & 68 firms in BIST (1990-1995) & Support \\
\hline Kula (2000) & 80 firms (1999) & Support \\
\hline Acaravcı \& Doğukanlı (2004) & 66 firms in BIST (1992-2002) & Support \\
\hline Karadeniz (2008) & 163 firms in BIST (1990-2006) & Support \\
\hline Demirhan (2009) & 40 firms in BIST (2003-2006) & Support \\
\hline Yıldız et al.(2009) & 138 firms in BIST (1998-2006) & Support \\
\hline Ata \& Ag (2010) & 42 firms in BIST (2003-2007) & Support \\
\hline Okuyan \& Tasci (2010) & 1,000 firms (1993-2007) & Support \\
\hline Gülşen \& Ülkütaş (2012) & 143 firms in BIST (1990-2005) & Support \\
\hline Bozkurt (2014) & 168 firms in BIST (2005-2011) & Support \\
\hline Acaravcı (2015) & 79 firms in BIST (1993-2010) & Support \\
\hline Köksal \& Orman (2015) & over 7,000 firms (1996-2009) & Support \\
\hline Uyar \& Güzelyurt (2015) & SMEs in Istanbul (2011) & Support \\
\hline
\end{tabular}


Since SMEs are financially constrained and have access problems to long-run financing, they have to depend on profits to finance especially short-run projects. On the contrary to larger firms, who can find financing sources other than credits, SMEs have to rely on bank credits for their funding. But SMEs credit costs are higher than the larger firms since banks (especially in Turkey) charge higher interest rates for SMEs. Therefore, SMEs profit increases while their debt ratio tends to decrease.

However, Yildız et al. (2009) and Acaravc1 (2015) support both pecking order theory and trade-off theory regressing different variables. They justify pecking order theory showing a negative relationship between debt and profitability while demonstrating a positive relationship between firms' capital structure and growth opportunities which justifies trade-off theory. Besides that, Güloğlu \& Bekçioğlu (2001) have claimed that development of the stock market substantially raises short-term debt rate and interestingly the effect on SMEs are larger than larger firms in Istanbul Stock Exchange (BIST). This implies that SMEs lever up quickly especially in the short-run when there are optimistic expectations in the economy, and maybe larger firms act more prudently due to better evaluation of the long-run and having access to more diverse finance. Ata \& Ag (2010) and Sarığlu et al. (2013) showed that there is a positive relationship between debt ratio and firm size, and larger firms have preferred to use tax shield more than SMEs. Therefore, these empirical findings support trade-off theory for Turkish firms.

Contrasting with the significant amount of studies supporting pecking order theory, according to Köksal \& Orman (2015) trade-off is a better theory to understand capital structure decisions of Turkish firms. Their divergence from the earlier studies relies on using a significantly exhaustive data set including firm- and sector-level financial determinants and having quite comprehensive analysis including nearly all nonfinancial sectors, as well as public and private firms. Their results hold regardless of the sector, firm size and presence in the stock market. They also conclude trade-off theory especially fits well during more stable economic conditions, whereas pecking order theory, even not as robust as trade-off theory, seems to explain the behavior of public manufacturing SMEs under unstable economic conditions.

Table 7: Summary of Methodology Applications on Trade-off Theory for Turkish Firms

\begin{tabular}{lcc}
\hline Author & Sample & Results \\
\hline Kula (2000) & 80 firms (1999) & Not support \\
\hline Güloğlu \& Bekçioğlu (2002) & 42 firms in BIST & Not support \\
\hline Yıldız et al. (2009) & 138 firms in BIST (1998-2006) & Support \\
\hline Ata \& Ag (2010) & 42 firms in BIST (2003-2007) & Support \\
\hline Gülşen \& Ülkütaş (2012) & 143 firms in BIST (1990-2005) & Not support \\
\hline Sarığlu et al. (2013) & 42 firms in BIST (2007-2011) & Support \\
\hline Bozkurt (2014) & 168 firms in BIST (2005-2011) & Not support \\
\hline Acaravcı (2015) & 79 firms in BIST (1993-2010) & Support \\
\hline Köksal \& Orman (2015) & over 7000 firms (1996-2009) & Support \\
\hline Uyar \& Güzelyurt (2015) & SMEs in Istanbul (2011) & Not support \\
\hline
\end{tabular}




\subsection{Signaling Theory}

Karmokolias et al. (1995) focused on developing countries including Turkey and concluded that firms in emerging markets put more emphasis on the dividend amount rather than dividend ratio implying an unstable dividend policy. Similarly, Aivazian et al. (2003) also found that emerging market economies have more unstable dividend policies compared to the US. In line with these results, Adaoğlu (2000) concluded that firms listed in BIST have unstable dividend payout as the most important determinant being annual earnings. His findings suggest that firms in developing countries, unlike the stable dividend policy of developed countries, do not use dividend policy as a signaling mechanism to investors. This contradictory result may be due to ownership structure and financing choices of firms in emerging markets. Without separation of ownership and control, bank-financed firms have more close information sharing with lenders resulting with reduced need for signaling through dividend policies.

Besides that, Günalp et al. (2010) claim that the decision to pay dividend is a crucial information affecting the stock return in Turkey. Shares of firms in the high cash dividend distribution lose more value than other firms unlike findings of Batchelor \& Orakçığlu (2003). Moreover, Aydoğan \& Muradoğlu (1998) mention the same conclusion which is a decrease in the market inefficiency of BIST in the last 20 years. These studies support signaling theory's suggestions.

Yıldiz et al. (2014) test 118 firms in BIST and found that leverage affects negatively the dividend policy, so this result does not support signaling theory. But they conclude that this result is due to the stabilized economic growth period in Turkey which helped the firms to have stable cash flow and dividend payout due to their optimistic expectations about the future. However, Aygören et al. (2013) analyze the effect of the crisis on dividend policy from 1986 to 2010 in BIST. Their results show that there is no fixed dividend payout ratio and dividend payment systems have structural breaks due to crisis effects.

Findings in the literature refute the hypothesis of signaling theory for Turkish firms at some level. The reason is twofold. First, as in most emerging markets, there are fewer agency problems especially in SMEs since they are managed usually by owners. Also, SMEs using mostly bank credit as external finance decreases information asymmetry between lenders and firms since banks usually can access confidential financial information. Thus, signaling to overcome information asymmetry is not needed for these firms. Moreover, contrary to the theoretical result of the negative relation between dividend payout and firm value, firms paid dividends. Firms pay out dividends due to stable cash flows. 
Table 8: Summary of Methodology Applications on Signaling Theory For Turkish Firms

\begin{tabular}{lcc}
\hline Author & Sample & Results \\
\hline Karmokolias et al. (1995) & Dividend payout in emerging markets & Not support \\
\hline Aydoğan \& Muradoğlu (1998) & 109 firms in BIST(1988-1993) & Support \\
\hline Aivazian et al. (2003) & Dividend policies of emerging markets & Not support \\
\hline Batchelor \& Orakçığlu (2003) & Shares of firms in BIST(1990-1994) & Not support \\
\hline Adaoğlu (2010) & 76 firms in BIST(1985-1997) & Not support \\
\hline Günalp et al. (2010) & 83 firms in BIST (2003-2007) & Support \\
\hline Aygören et al. (2013) & 600 firms in BIST (1986-2010) & Support \\
\hline Yıldız et al. (2014) & 118 firms in BIST (2003-2010) & Not support \\
\hline
\end{tabular}

\section{Capital Structure Decisions and the Global Financial Crisis in Turkey}

Turkish firms also changed critically their structure and maturity of debt during the GFC (Yıldız, 2018; Jermias \& Yigit, 2019). Using BIST data, Y1ldız (2018) shows that the GFC negatively affected the adjustment speed of leverage of Turkish firms. Jermias \& Yigit (2019) also confirm the inverse trend on the adjustment speed of leverage after the GFC. Besides, employing CBRT data, Köksal \& Orman (2015) and Orman \& Köksal (2017) find that both listed and unlisted (small or private) Turkish firms may change their capital structure decisions depending on whether the economy is stable or not. However, to date, no single study has examined the impact of the GFC on Turkish small or private firms by using the CBRT dataset.

Table 9: Summary of Recent Selected Studies on Capital Structure and The GFC in Turkey

\begin{tabular}{lcccc}
\hline Author & Dataset & Period & Sample firms & GFC impact \\
\hline Köksal \& Orman (2015) & CBRT & $1996-2009$ & Listed / unlisted & $\times$ \\
\hline Orman \& Köksal (2017) & CBRT & $2004-2013$ & Listed / unlisted & $\times$ \\
\hline Yıldız (2018) & BIST & $2003-2016$ & Listed & $\checkmark$ \\
\hline Jermias \& Yigit (2019) & BIST & $1989-2012$ & Listed & $\checkmark$ \\
\hline
\end{tabular}

\section{Conclusion}

Considering the importance of SMEs as the backbone of the Turkish economy, this study aims to analyze the capital structure decision behavior of SMEs. Since SMEs face more problems while accessing finance, capital structure choices become more crucial for their survival, especially under crisis conditions. Thus, Trade-off Theory, Pecking Oder Theory, and Signaling Theory are discussed in detail to gain insight into Turkish SMEs' financing choices and to understand whether SMEs take precautionary steps under the severe crisis conditions. 
Trade-off theory assumes that firms set a target debt-to-level ratio derived from the optimal trade-off between the benefits and costs of debt. Considering the financial constraints of Turkish SMEs, trade-off theory seems an invalid theory empirically since SMEs cannot usually directly issue debt or equity, meaning that they have to rely on internal funding. Therefore, pecking order theory seems a better fit for explaining the capital structure decisions of Turkish SMEs (Güloğlu \& Bekçioğlu, 2001; Köksal \& Orman, 2015), since it does not assume optimality. Pecking order theory states that firms choose between alternative financing options to finance their investments in a certain order, namely first use the retained earnings, then debt and finally equity.

The contribution of this study is manifold. First, it lays the ground for future studies by pointing out that signaling theory has not been directly tested for the Turkish SMEs. Moreover, to the best of our knowledge, there has not been any study focusing on the impact of the GFC on capital structure behavior of unlisted firms in Turkey. Thus, our review offers a possible research avenue to understand the capital structure decisions of Turkish SMEs in the GFC context, considering the important role SMEs play in the Turkish economy.

\section{References}

Acaravc1, S. K. (2015). The determinants of capital structure: Evidence from the Turkish manufacturing sector. International Journal of Economics and Financial Issues, 5(1), 158-171.

Acaravcı, S. \& Doğukanlı, H. (2004). Türkiye'de sermaye yapısını etkileyen faktörlerin imalat sanayinde sinanmas1. Iktisat İsletme ve Finans, 19(225), 43-57.

Adaoğlu, C. (2000). Stability in the dividend policy of the Istanbul Stock Exchange (ISE) corporations: Evidence from an emerging market. Emerging Markets Review, 1, 252-270.

Aivazian, V., Booth, L., \& Cleary, S. (2003). Do emerging market firms follow different dividend policies from US firms? Journal of Financial Research, 26(3), 371-387.

Akerlof, G. A. (1970). The market for" lemons": Quality uncertainty and the market mechanism. Quarterly Journal of Economics, 84(3), 488-500.

Alves, P., \& Francisco, P. (2015). The impact of institutional environment on the capital structure of firms during recent financial crises. The Quarterly Review of Economics and Finance, 57, 129-146.

Amin, A. S., Dutta, S., Saadi, S., \& Vora, P. P. (2015). Institutional shareholding and information content of dividend surprises: Re-examining the dynamics in dividend-reappearance era. Journal of Corporate Finance, 31, 152-170.

Antweiler, W., \& Frank, M. Z. (2006). Do US stock markets typically overreact to corporate news stories. Available at SSRN, No: 878091.

Arnold, L. G., Reeder, J., \& Trepl, S. (2014). Single name credit risk, portfolio risk and credit rationing. Economica, 81(322), 311-328.

Ata, H. A., \& Ag, Y. (2010). Firma karakteristiğinin sermaye yapısı üzerindeki etkisinin analizi. İstanbul Üniversitesi İktisat Fakültesi Ekonometri ve İstatistik Dergisi, 11, 45-60.

Aydoğan, K., \& Muradoğlu, G. (1998). Do markets learn from experience? Price reaction to stock dividends in the Turkish market. Applied Financial Economics, 8(1), 41-49.

Aygören, H., Çakır, H. M., \& Uyar, U. (2013). Ekonomik krizlerin İMKB'de temettui politikaları üzerine etkisi. NWSA: Social Sciences, 8(1), 1-15.

Baker, H. K., Powell, G. E., \& Veit, E. T. (2003). Why companies use open-market repurchases A managerial perspective. Quarterly Review of Economics and Finance, 43(3), 483-504. 
Baltagi, B. (2008). Econometric analysis of panel data. $4^{\text {th }}$ Edition, USA: John Wiley \& Sons.

Batchelor, R., \& Orakçığlu, I. (2003). Event-related GARCH: The impact of stock dividends in Turkey. Applied Financial Economics, 13(4), 295-307.

Bebczuk, R. N. (2003). Asymmetric information in financial markets: Introduction and applications. Cambridge: Cambridge University Press.

Berger, A. N. (2006). Pecking order theoryential competitive effects of Basel II on banks in SME credit markets in the United States. Journal of Financial Services Research, 29(1), 5-36.

Bhattacharya, S. (1979). An exploration of nondissipative dividend-signaling structures. Journal of Financial and Quantitative Analysis, 14(4), 667-668.

Booth, L., Aivazian, V., Demirgüç-Kunt, A. \& Maksimovic, V. (2001). Capital structures in developing countries. Journal of Finance, 56(1), 87-130.

Bozkurt, I. (2014). Dengeleme Teorisi'nin geçerliliğinin panel veri analizi ile test edilmesi: BİST'de ampirik bir uygulama. Yönetim ve Ekonomi, 21(2), 163-178.

Bradley, M., Jarrell, G. A., \& Han Kim, E. (1984). On the existence of an optimal capital structure: Theory and evidence. Journal of Finance, 39(3), 857-878.

Brau, J. C., \& Carpenter, J. T. (2012). Small-Firm uniqueness and signaling theory. Journal of Business Economics and Finance, 1(1), 50-63.

Brealey, R. A., Myers, S. C., \& Allen, F. (2014). Principles of corporate finance. $11^{\text {th }}$ Edition, Berkshire: McGraw-Hill Education.

Brennan, M., \& Kraus, A. (1987). Efficient financing under asymmetric information. Journal of Finance, 42(5), 1225-1243.

Can, E. (2015). KOBİ'lerin finansman desteği açısından kredi ve sermaye piyasalarının bütünleşmesi ve KOBİ menkul kıymetleştirme uygulaması. Türkiye Bankalar Birliği, Bankacılar Dergisi, 26(92), 25-52.

D'Amato, A. (2019). Capital structure, debt maturity, and financial crisis: Empirical evidence from SMEs. Small Business Economics, 1-23.

Degryse, H., De Goeij, P., \& Kappert, P. (2012). The impact of firm and industry characteristics on small firms' capital structure. Small Business Economics, 38(4), 431-447.

Demirgüç-Kunt, A., Peria, M. S. M., \& Tressel, T. (2020). The global financial crisis and the capital structure of firms: Was the impact more severe among SMEs and non-listed firms?. Journal of Corporate Finance, 60, 101514.

Demirhan, D. (2009). Sermaye yapısını etkileyen firmaya özgü faktörlerin analizi: $I M K B$ hizmet firmaları üzerine bir uygulama. Ege Academic Review, 9(2), 677-697.

Durukan, B. (1997). Hisse senetleri İMKB'de işlem gören firmaların sermaye yapısı üzerinde bir araştırma. İMKB Dergisi, 1(3), 75-91.

Eckbo, B. E. (1986). Valuation effects of corporate debt offerings. Journal of Financial Economics, 15(1), 119-151.

Erdoğan, M. (2008). Bankacılık sektöründe asimetrik bilgi: Sorunlar ve çözüm önerileri. Dumlupınar Üniversitesi Sosyal Bilimler Dergisi, 20, 1-20.

Fama, E. F., \& French, K. R. (2002). Testing trade_off and pecking order predictions about dividends and debt. Review of Financial Studies, 15(1), 1-33.

Faulkender, M., Flannery, M. J., Hankins, K. W., \& Smith, J. M. (2012). Cash flows and leverage adjustments. Journal of Financial Economics, 103(3), 632-646. 
Fischer, E. O., Heinkel, R., \& Zechner, J. (1989). Dynamic capital structure choice: Theory and tests. Journal of Finance, 44(1), 19-40.

Flannery, M. J., \& Rangan, K. P. (2006). Partial adjustment toward target capital structures. Journal of Financial Economics, 79(3), 469-506.

Frank, M. Z., \& Goyal, V. K. (2003). Testing the pecking order theory of capital structure. Journal of Financial Economics, 67(2), 217-248.

Frank, M. Z., \& Goyal, V. K. (2008). Tradeoff and pecking order theories of debt. In: B. E. Eckbo (eds.), Handbook of corporate finance: Empirical corporate finance (pp. 135-202). Amsterdam: NorthHolland.

Ghosh, C., Nag, R., \& Sirmans, C. (1999). An Analysis of seasoned equity offerings by equity REITs. Journal of Real Estate Finance and Economics, 13(3), 175-192.

Gonzalez, V. M., \& Gonzalez, F. (2012). Firm size and capital structure: Evidence using dynamic panel data. Applied Economics, 44(36), 4745-4754.

Gonzalez, V. M. (2015). The financial crisis and corporate debt maturity: The role of banking structure. Journal of Corporate Finance, 35, 310-328.

Graham, J. R. (2000). How big are the tax benefits of debt?. Journal of Finance, 55(5), 1901-1941.

Graham, J. R., \& Harvey, C. R. (2001). The theory and practice of corporate finance: Evidence from the field. Journal of Financial Economics, 60(2), 187-243.

Güloğlu, B., \& Bekçioğlu, S. (2001). İMKB'deki gelişmelerin şirketlerin sermaye yapısına etkileri: İmalat sanayinde faaliyet gösteren firmalar üzerine bir uygulama. ODTÜ Uluslararası İktisat Kongresi.

Gülşen, A. Z., \& Ülkütaş, O. (2012). Sermaye yapısının belirlenmesinde finansman hiyerarşisi teorisi ve ödünleşme teorisi: İMKB sanayi endeksinde yer alan firmalar üzerine bir uygulama. Uluslararası Yönetim İktisat ve Issletme Dergisi, 8(15), 49-59.

Günalp, B., Kadığ̆lu, E., \& Kılıç, S. (2010). Nakit temettü bilgisinin hisse senedi getirisi üzerinde önemli bir etkisinin olup olmadığının İMKB'de test edilmesi. HÜ İktisadi ve İdari Bilimler Fakültesi Dergisi, 28(2), 47-69.

Hovakimian, A., Opler, T., \& Titman, S. (2001). The debt-equity choice. Journal of Financial and Quantitative Analysis, 36(01), 1-24.

Huang, G., \& Song, F. (2006). The determinants of capital structure: Evidence from China. China Economic Review, 17(1), 14-36.

Jain, B. A., \& Kini, O. (1994). The post-issue operating performance of IPO firms. Journal of Finance, 49(5), 1699-1726.

Jegadeesh, N., \& Titman, S. (1993). Returns to buying winners and selling losers: Implications for stock market efficiency. Journal of Finance, 48(1), 65-91.

Jensen, M. C., \& Meckling, W. H. (1976). Theory of the firm: Managerial behavior, agency costs, and ownership structure. Journal of Financial Economics, 3(4), 305-360.

Jermias, J., \& Yigit, F. (2019). Factors affecting leverage during a financial crisis: Evidence from Turkey. Borsa Istanbul Review, 19(2), 171-185.

Karadeniz, E. (2008). Türk konaklama işletmelerinde sermaye yapısını etkileyen faktörlerin analizi (Yayımlanmamış Doktora Tezi). Çukurova Üniversitesi, Sosyal Bilimler Enstitüsü.

Karmokolias, Y., Miller, R. R., Shah, S., \& Mundial, B. (1995). Dividend policy and behavior in emerging markets: To pay or not to pay. Washington DC: World Bank.

Kayhan, A., \& Titman, S. (2007). Firms' histories and their capital structures. Journal of Financial Economics, 83(1), 1-32. 
Köksal, B., \& Orman, C. (2015). Determinants of capital structure: Evidence from a major developing economy. Small Business Economics, 44(2), 255-282.

KOSGEB (2012). Enhancing the competitiveness of SMEs in Turkey: Country report.

Kraus, A., \& Litzenberger, R. H. (1973). A state-preference model of optimal financial leverage. Journal of Finance, 28(4), 911-922.

Kula, V. (2000). Küçük ve orta ölçekli imalat işletmelerinin sermaye yapısını etkileyen faktörler ve Afyon'daki işletmeler üzerine bir araştırma (Yayımlanmamış Doktora Tezi). Afyon Kocatepe Üniversitesi.

Leary, M.T., \& Roberts, M. R. (2005). Do firms rebalance their capital structures?. Journal of Finance, 60(6), 2575-2619.

Leland, H. E., \& Pyle, D. H. (1977). Informational asymmetries, financial structure, and financial intermediation. Journal of Finance, 32(2), 371-387.

Lemmon, M. L., Roberts, M. R., \& Zender, J. F. (2008). Back to the beginning: Persistence and the cross -section of corporate capital structure. Journal of Finance, 63(4), 1575-1608.

Lemmon, M. L., \& Zender, J. F. (2010). Debt capacity and tests of capital structure theories. Journal of Financial and Quantitative Analysis, 45(5), 1161-1187.

López-Gracia, J., \& Sogorb-Mira, F. (2008). Testing trade-off and pecking order theories financing SMEs. Small Business Economics, 31(2), 117-136.

Loughran, T., \& Ritter, J. R. (1997). The operating performance of firms conducting seasoned equity offerings. Journal of Finance, 52, 1823-1850.

Masulis, R. W. (1980). The effects of capital structure change on security prices: A study of exchange offers. Journal of Financial Economics, 8(2), 139-178.

Michaelas, N., Chittenden, F., \& Poutziouris, P. (1999). Financial policy and capital structure choice in UK SMEs: Empirical evidence from company panel data. Small Business Economics, 12(2), 113-130.

Mimouni, K., Temimi, A., Goaied, M., \& Zeitun, R. (2019). The impact of liquidity on debt maturity after a financial crisis: Evidence from the Gulf Cooperation Council region. Emerging Markets Finance and Trade, 55(1), 181-200.

Mishkin, F. S. (2007). The economics of money, banking, and financial markets. New Jersey: Pearson Education.

Modigliani,F., \& Miller, M.H. (1958). The cost of capital, corporate finance, and the theory of investment. American Economic Review, 48(4), 261-97.

Miller, M. H., \& Modigliani, F. (1961). Dividend policy, growth, and the valuation of shares. The Journal of Business, 34(4), 411-433.

Modigliani, F., \& Miller, M. H. (1963). Corporate income taxes and the cost of capital: A correction. American Economic Review, 53(3), 433-443.

Morellec, E. (2004). Can managerial discretion explain observed leverage ratios?. Review of Financial Studies, 17(1), 257-294.

Muslumov, A., \& Aras, G. (2004). Kredi piyasalarında asimetrik bilgi ve bankacılık sistemi üzerindeki etkileri. Íktisat, İsletme ve Finans Dergisi, 222, 55-65.

Myers, S. C. (1984). The capital structure puzzle. Journal of Finance, 39(3), 574-592.

Myers, S. C., \& Majluf, N. (1984). Corporate financing and investment decisions when firms have information that investors do not have. Journal of Financial Economics, 13(2), 187-221. 
Myers, S. C. (2001). Capital structure. Journal of Economic Perspectives, 15(2), 81-102.

Nissim, D., \& Ziv, A. (2001). Dividend changes and future profitability. Journal of Finance, 56(6), 21112133.

OECD (2005). OECD SME and entrepreneurship outlook: 2005. Paris: OECD Publishing.

OECD (2006). Financing SMEs and entrepreneurs. Paris: OECD Publishing.

Okuyan, H.A., \& Taşçı, H.M. (2010). Sermaye yapısının belirleyicileri: Türkiye'deki en büyük 1000 sanayi işletmesinde bir uygulama. BDDK Bankacılık ve Finansal Piyasalar Dergisi, 4(1), 105120.

Orman, C., \& Köksal, B. (2017). Debt maturity across firm types: Evidence from a major developing economy. Emerging Markets Review, 30, 169-199.

Rajan, R. G., \& Zingales, L. (1995). What do we know about capital structure? Some evidence from international data. Journal of Finance, 50(5), 1421-1460.

Ross, S. A. (1977). The determination of financial structure: The incentive-signaling approach. The Bell Journal of Economics, 8(1), 23-40.

Sarığlu, S. E., Kurun, E., \& Güzeldere, H. (2013). Sermaye yapısının belirleyicileri: İMKB'de işlem gören çimento, otomotiv ve bilişim sektörlerinin sermaye yapısı analizi. Ege Akademik Baklş, 13(4), 481-496.

Seker, S. D., \& Jenkins, S. P. (2015). Poverty trends in Turkey. The Journal of Economic Inequality, 13(3), 401-424.

Shah, K. (1994). The nature of information conveyed by pure capital structure changes. Journal of Financial Economics, 36(1), 89-126.

Shyam-Sunder, L., \& Myers S.C. (1999). Testing static tradeoff against pecking order models of capital structure. Journal of Financial Economics, 51(2), 219-44.

Spence, M. (1973). Job market signaling. The Quarterly Journal of Economics, 87(3), 355-374.

Spence, M. (2002). Signaling in retrospect and the informational structure of markets. American Economic Review, 92, 434-459.

Stiglitz, J. E., \& Weiss, A. (1981). Credit rationing in markets with imperfect information. American Economic Review, 71(3), 393-410.

Strebulaev, I. A. (2007). Do tests of capital structure theory mean what they say. Journal of Finance, 62(4), 1747-1787.

Strebulaev, I. A., \& Yang, B. (2013). The mystery of zero-leverage firms. Journal of Financial Economics, 109(1), 1-23.

Titman, S., \& Wessels, R. (1988). The determinants of capital structure choice. Journal of Finance, 43(1), $1-19$.

Tserlukevich, Y. (2008). Can real options explain financing behavior. Journal of Financial Economics, 89(2), 232-252.

Uyar, A., \& Güzelyurt, M. K. (2015). Impact of firm characteristics on capital structure choice of Turkish SMEs. Managerial Finance, 41(3), 286-300.

Walker, G., \& Weber, D. (1984). A transaction cost approach to make-or-buy decisions. Administrative Science Quarterly, 29(3), 373-391.

World Bank. (2011). Turkey: Improving conditions for SME growth, finance and innovation, private and financial sector report. Washington DC: World Bank. 
Yıldız, B., Gökbulut, R. İ., \& Korkmaz, T. (2014). Firmalarda temettü politikalarini etkileyen unsurlar: BİST sanayi işletmeleri üzerine bir panel veri uygulamasi. AİB̈̈-İIBF Ekonomik ve Sosyal Araştırmalar Dergisi, 10(1), 185-206.

Yıldız, M. E., Yalama, A., \& Sevil, G. (2009). Sermaye yapısı teorilerinin geçerliliğinin test edilmesi: Panel veri analizi kullanılarak İMKB-imalat sektörü üzerinde ampirik bir uygulama. Iktisat Isletme ve Finans, 24(278), 25-45.

Yildız, Y. (2018). Adjustment to target capital structure and global financial crisis: Evidence from Turkey. Business and Economics Research Journal, 9(3), 543-557.

Zeitun, R., Temimi, A., \& Mimouni, K. (2017). Do financial crises alter the dynamics of corporate capital structure? Evidence from GCC countries. The Quarterly Review of Economics and Finance, 63, 21-33.

Zhou, P., \& Ruland, W. (2006). Dividend payout and future earnings growth. Financial Analysts Journal, 62(3), 58-69. 